\title{
TOTAL QUALITY MANAGEMENT PRACTICES TO ENHANCE ORGANIZATIONAL PERFORMANCE BY COMPETITIVE ADVANTAGE AS MEDIATING IN SMEs IN IRAQ
}

\author{
Mohammed Mahdi Ukab \\ Technical College of Management/Baghdad, Middle Technical University, \\ Baghdad, Iraq \\ Mohammed1986.hm@gmail.com
}

\begin{abstract}
Effective improvement in quality has become a potentially precious way to boost competitiveness and organizational performance. This paper aims to assess for competitive advantage and organizational performance the effects of Total quality management (TQM) activities.

A quantitative approach is used to obtain data from a survey (questionnaire) consisting of 38 items with a fivepoint Likert scale.

The unit of analysis is small and medium food companies in Iraq. The respondents in this paper are the managers of departments. Smart PLS 3.2.9 was used to analyze the results. The findings of the path analysis of partial least squares (PLS) support variables in their hypothesised direct relationships with organizational performance.

The analysis results suggest that competitive advantage partially mediates the relationship between (TQM) practices and organizational performance. The paper provides many suggestions that are helpful both for researchers and policymakers to undertake more research in this area as well as to enhance the (CA) and (OP) of organisations in the future.
\end{abstract}

KEYWORDS: Competitive Advantage (CA), Organizational Performance (OP), Total Quality Management Practices (TQMP).

Article Received: 5 January 2021, Revised: 25 January 2021, Accepted: 18 February 2021

1. Introduction

With the intensification of competition and the globalization of economies, quality has become an increasing priority within organisations(Singh \& Smith, 2006).

In order to boost (OP) and remain competitive, several businesses have increased the quality of their services and goods(Saleh et al., 2018).

In particular, production firms are faced with an increasingly competitive and demanding climate. Therefore, they should be able to create conditions that support them both in the domestic and international markets(Nguyen \& Chau, 2017).

However, the effect of quality on organizational performance is still being debated amid almost three decades of research on quality improvements (Chege \& Bett, 2019).

In fact, if certain studies have shown that improving quality led to better results for the company(Kiprotich et al., 2018; Saleh et al., 2018; Phan et al., 2019;Rui Chen, 2018;Nguyen \& Chau, 2017;Davcik, 2016;Eniola \& Ektebang, 2014).
Most researchers find out a positive relationship between TQM practices and performance. Empirically, However, lack of the studies which test the relationship between TQM practices, competitive advantage, and organizational performance in the literature.

Therefore, the aim of this paper is to empirically evaluate a structure that defines quality, competitive advantage, and organizational performance relationships.

Hence the research question that emanates from the objective is 'To what extent does Total Quality Management impacts organizational performance through Competitive Advantage in the small and medium food companies in Iraq?

This paper contributes to growing literature in the area of Total Quality Management research in companies in developing countries like Iraq.

\section{Theoretical Framework} Total Quality Management Practices In the past 20 years, the value of (TQM) in industries has increased dramatically (Khan et al., 2020). The quality aspect has been highly prized 
by organizations because of the increasing competitiveness within the global marketplace; in return, TQM has become a key management issuance (Suresh \& Ganesan, 2020).

In Japan, the USA, Europe and the developing countries several studies have addressed absolute quality management(Kiprotich et al., 2018). There is no single uniformly accepted approach to TQM (Saleh et al., 2018).

Regarding quality, Chege and Bett (2019) Developing all the processes, jobs, money, outcomes, individual, time, place and managerial approach. In addition, Obeidat et al. (2019)TQM is considered to be one of the world's new theories of administration, comprising a set of modern principles focused on fundamental administrative tools and creativity that enhances efficiency and ensures continuous improvement. For that there are those who know the total quality management as excellence it and excel, others see it as reducing defects in products or services, and others assume that the term is based on the aims of the organization, According(Obeidat et al., 2019).

Total quality management benefits include increased performance of management, versatility and competitiveness, improved (OP), and customer satisfaction led to organizational success and both organizational and social members have shared benefits (Pham, 2020).

\section{Competitive advantage}

Competitive advantage denotes the ability of a company to gain market dominance over its rivals. A competitive advantage offers super-average efficiency in the long run(Kaleka et al., 2017). There are six characteristics of a strong competitive advantage: customer wishes and needs to drive it. It makes a major contribution to the performance of the business; it combines the specific resources of the company with the opportunities in the market(Falih et al., 2020). No two businesses have the same resources; a successful strategy efficiently exploits them; it is long-lasting and hard to replicate for rivals(Lestari et al., 2020). For instance, a department of superior research and development may continually create new technologies or processes to remain ahead of competitors; it offers a foundation for further progress. It provides the entire business with direction and encouragement. Considering that each of these features relates to price, the price can be an essential means to achieve a competitive advantage. Let's see how robust coherence gives to a (CA)(Anwar, 2018). Address cost leadership, distinction, and assets as significant sources of competitive advantage, and their quality relationships; Relate quality to achieving higher profitability; explain the value of quality in meeting product growth, organizational, flexibility and variety, innovation and fast responses to customer requirements and fix quality impacts on market outcomes(Eniola \& Ektebang, 2014).

\section{Organizational Performance}

Performance measurement is very important for effective management in an organization. According to (Deming) Anything cannot improve it without measuring. (OP) refers to the degree to which a company accomplished its business objectives and financial objectives (Li et al., 2006). Academics also do not explain organizational success in depth. The standard method of calculating success using only financial performance metrics is faulty. A number of previous studies have evaluated organizational performance on the basis of both financial and business criteria, including ROI, the profit margin on revenue, market share, ROI growth, market share growth and sales growth(Agha et al., 2012).

\section{Total Quality Management and Competitive Advantage}

This section discusses quality dimension and competitive advantage to highlight the linkages involved. The major objective of TQM is the search for customer satisfaction also it is a call for an organizational commitment to meeting or exceeding customer expectations (Rui Chen, 2018). This is borne from the knowledge that the customer is the organization's "raison d'être", its purpose for existence without the customer, an organization cannot survive(Nguyen \& Chau, 2017).

The competitive advantage lies in the production and delivery of value logic (Esiaba, 2016). The competitive profit of an organization is stated as being higher than the value generated in economic exchanges (Addae-Korankye, 2013). In addition, it also gives an awareness that the resources possessed by an organization and the business plan have a profound effect on the generation of competitive advantages as the ability to remain ahead from the existing or future competition.

TQM is an applied management methodology, which has been developed to strongly affect corporate results. TQM has become the key slogan for a corporate competition (Munizu, 2013).

Total Quality Management aims at improving the productivity of businesses through the emphasis on employee engagement and continuous quality enhancement of goods, facilities, personnel, 
processes and customer satisfaction(Laframboise \& Reyes, 2005).

A study conducted by Douglas and Judge (2001) revealed that in Ghana, several organizations are underperforming and finally collapsing because they have relegated quality management to the background. In this modern business environment, customers can make or unmake a company and organizations should put quality at the top of their priorities to gain competitive advantage, for the most part, utilities or manufacturing companies treat customers like beggars. Employee quality is very critical, but it is overlooked by most companies. Because most companies neglect their employees' education and growth, employees manufacture inferior items(Yanya \& Mahamat, 2020).

The consumers' awareness has increased with product and service quality levels arising from market trends, which contributes to greater demands and is also seen as economically competitive to meet consumer needs(Azizi et al., 2016).

Recognition of total quality control as a source of competitive advantage is widely spread throughout the world, especially in western countries(AddaeKorankye, 2013).

There are only a handful of companies today (particularly in the industry) this idea can be ignoredComprehensive quality management performance will boost employee engagement, improve communication, enhance productivity, improve quality, minimize costs and improve competitive advantage (Othman et al., 2020). However, intense competitive demands pressured companies to deliver high-quality goods and services in a way that attracted and retained customers.

\section{Total Quality Management and Organizational Performance}

General description of (TQM) is a collective integrated quality management framework that is related to organizational performance (Saleh et al., 2018). TQM has probably been the most significant approach to manage operations improvement.

An appreciation of the concepts of quality control is the basis for any changes (Phan et al., 2019). As a result of the intense global competition, the idea of total quality management (TQM) was created. The TQM philosophies, processes, tools and strategies have attracted extensive attention from international trade and global competition organisations(Kiprotich et al., 2018).
Many businesses actually adopt the TQM approach and quality measures in order to achieve sustainable competitive benefits and improved company performance (Khan et al., 2020).

Awino et al. (2012) studies have explored the positive ties between TQM and different performance measures.

Study Nguyen and Chau (2017) For the link between TQMP and organizational performance, evaluated the practices of TQM and organizational performance in 400 construction companies in Hanoi with six factors, including market and profitability, customer satisfaction, employee satisfaction, process efficiency, process effectiveness and order time. The research demonstrated the strong relationship between both by using multiple regression analysis. The research only studied the building and organizational performance in Hanoi.

FoundChege and Bett (2019) that a significant positive association between organizational performance and all dimensions of quality management practices. Phan et al. (2019)study Specifically, TQM, such as: management, management, management of systems, engagement of workers and emphasis on customers, are widely agreed to boost companies' performance.

\section{Competitive Advantage and Organizational Performance}

In today's competitive market, the competitive advantage has gained enough attention because it contributes significantly to the company's success(Davcik, 2016).

Kamukama et al. (2011)Proposed that companies offer their customers in the markets, by modifying their differentiation strategy, single goods, and products give the competition and competing companies a monopoly advantage.

The businesses, therefore, charge higher rates that add to profits. Companies that value the technique of cost control often reduce the various costs of equipment, supply, product creation, operations, etc.(Kang \& Na, 2020). Which boost profitability on the one hand and consumers on the other buy bulk goods, leading to higher profitability.In comparison, businesses with a lower competitive advantage lose their performance and fear of business failure while the highly competitive advantage leads to high performance on the market (Eniola \& Ektebang, 2014). Since consumers view the goods as new, companies with innovative and novel products will earn high profit.

Some consumers are aware of prices and tend to buy goods at lower cost and bulk, thus increasing profitability in the pursuit of sustainable 
strategies.Many studies have concluded that the competitive advantage and performance of organizations are positive(Kang \& Na, 2020).

study Zhou et al. (2009), conducted by a strong relationship exists that exists between competitive advantage and corporate success, competitive advantage may predict significantly the variance of the organization's performance.

Morgan et al. (2012) also supported this study the Performance appliance and manipulation of known internal resources of companies is increased by using competencies.

Rose et al. (2010) It was established that the Resource-Based View of the companies'scompetitive advantage is one of the keys of strategic management theories related to explain the organizational consequences.

Current literature has well recorded the positive influence of the competitive advantage on performance because the competitive advantage gives a business the ability to surpass its competitors.

\section{Methodology}

In this paper, an attempt was made to study the relationship between TQM practices and competitive advantage and organizational performance within SMEs in Iraq. A quantitative methodology was taken in which the data collected were separated into two sections by a survey.
The first section focusses on the general features of the subjects, including age group, occupation, educational level, and Years of service.

In the second section, measuring the components of TQM practices and competitive advantage and organizational performance was our interest, a representative sample is crucial if evidence from the sample is being used to generalize the broader population from which the sample was chosen.

The study was applied to a sample of (123) heads of departments from the SMEs in Iraq.

The participants were invited to give their opinions on a Likert-scale (1-5) ranged from "Extreme Disagreement" to "High Agreement to analyze data obtained using a Smart pls 3. The theory is evaluated with partly smallest square structural equational modelling.In various ways such as efficient statistical modelling, prediction and the absence of sample size constraints, PLS-SEM is superior to other statistical methods and is particularly suited for mediation and accuracy, soft modelling assumptions do not require the standard nature of the data(Hair Jr. et al. 2017).

\subsection{Conceptual Framework}

The conceptual framework of(Bani et al., 2018) has an essential part in research to explain the methodology used for the study.A conceptual structure is therefore important to guide this research to its target. As seen in the figure. 2the author has developed a clear conceptual framework for this paper.

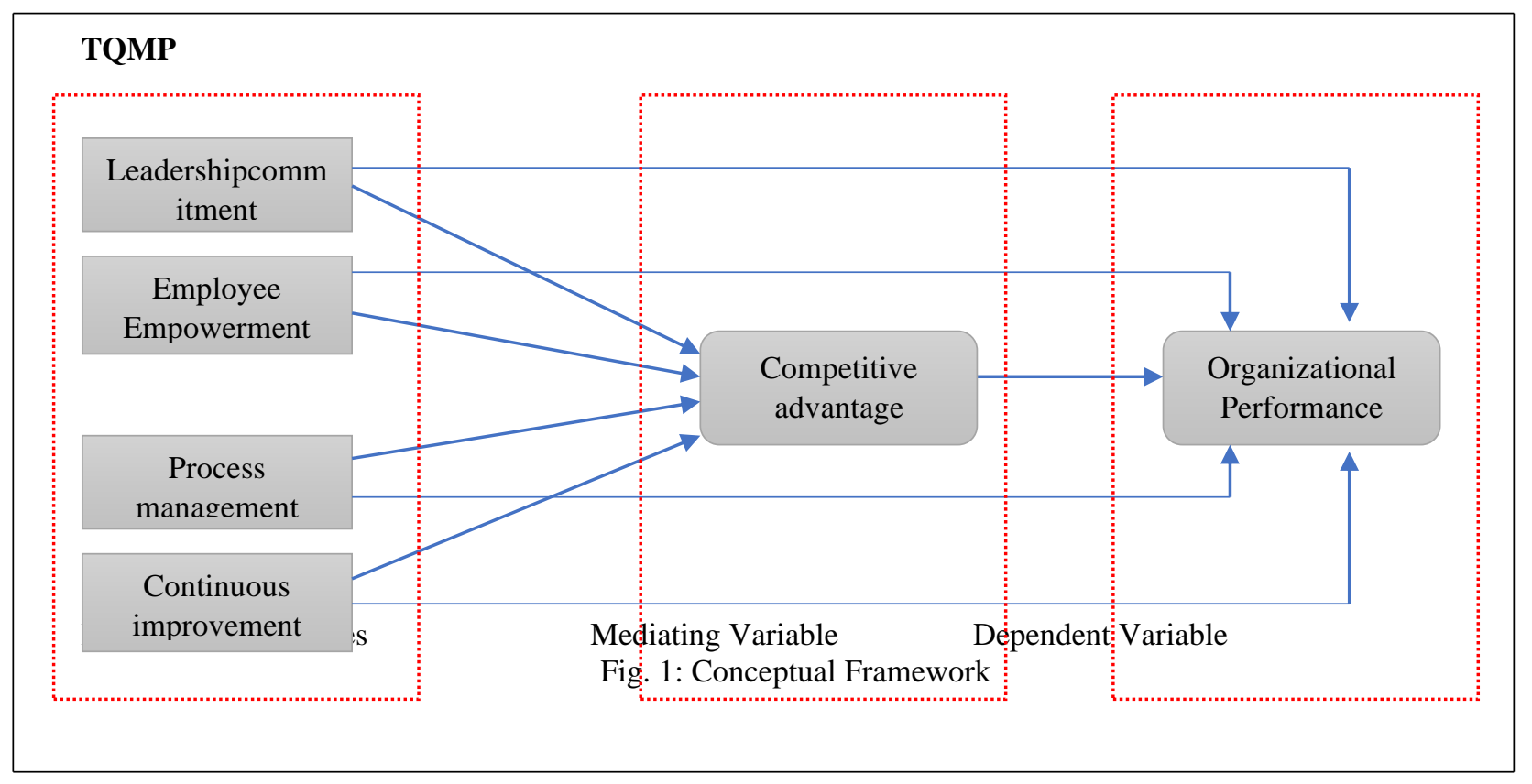




\section{Empirical Results and Discussion}

4.1Profile of population

Table 1 Displays general features of respondents, including gender, age, educational level, and years of service:

Table 1: Profile of population

\begin{tabular}{|c|c|c|c|c|}
\hline Variable & Category & Frequency & Percentage $\%$ & $\begin{array}{c}\text { Total } \\
\text { sampling }\end{array}$ \\
\hline \multirow{2}{*}{ Gender } & Male & 73 & 59.3 & \multirow{2}{*}{123} \\
\hline & Female & 50 & 40.7 & \\
\hline \multirow{4}{*}{ Age } & $30-20$ & 7 & 5.7 & \multirow{4}{*}{123} \\
\hline & $40-31$ & 30 & 24.4 & \\
\hline & $50-41$ & 66 & 53.6 & \\
\hline & 50 And Over & 20 & 16.3 & \\
\hline \multirow{4}{*}{ Educational } & Diploma & 13 & 10.6 & \multirow{4}{*}{123} \\
\hline & Bachelor & 73 & 59.3 & \\
\hline & Master & 28 & 22.8 & \\
\hline & Ph.D. & 9 & 7.3 & \\
\hline \multirow{4}{*}{ Years of service } & More Than 5-10 & 21 & 17.1 & \multirow{4}{*}{123} \\
\hline & More Than $10-15$ & 33 & 26.8 & \\
\hline & More Than 15-20 & 46 & 37.4 & \\
\hline & 20 And Over & 23 & 18.7 & \\
\hline
\end{tabular}

\subsection{Convergent validity}

Convergent validity is defined as "subcategories of construct validity", is assessed to validate the measurement model. Average Variance Extracted (AVE) is used to calculate the proportion of the Variance described by way of metrics for calculation errors. The lowest recommended reliability level is 0,7 based on the PLS review (Hair et al., 2017), And Average Variance Extracted (AVE) level 0.5 is the minimum acceptable level. As seen in Table 2 and fig.3, composite reliability and Cronbach's Alpha are deployed to evaluate the internal consistency reliability of each dimension. If the alpha coefficient of each part of a building in general exceeds 0.7 , the objects are considered highly trustworthy(Kannan \& Tan, 2005). The products were considered to be extremely accurate because the alpha coefficients of the individual Cronbach structures were over 0.7 .

Table 2: The product of convergent variables of validity

\begin{tabular}{|c|c|c|c|c|c|c|}
\hline Variables & Construct & Items & $\begin{array}{c}\text { Outer } \\
\text { Loading }\end{array}$ & $\begin{array}{c}\text { Cronbach's } \\
\text { Alpha }\end{array}$ & $\begin{array}{l}\text { Composite } \\
\text { Reliability }\end{array}$ & AVE \\
\hline \multirow{19}{*}{ 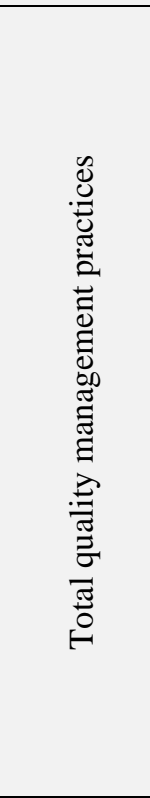 } & \multirow{5}{*}{$\begin{array}{l}\text { Leadership } \\
\text { Commitment }\end{array}$} & LC1 & 0.939 & \multirow{5}{*}{0.935} & \multirow{5}{*}{0.951} & \multirow{5}{*}{0.7950} \\
\hline & & $\mathrm{LC} 2$ & 0.930 & & & \\
\hline & & LC3 & 0.936 & & & \\
\hline & & LC4 & 0.827 & & & \\
\hline & & LC5 & 0.818 & & & \\
\hline & \multirow{5}{*}{$\begin{array}{c}\text { Employee } \\
\text { Empowerment }\end{array}$} & EE1 & 0.852 & \multirow{5}{*}{0.882} & \multirow{5}{*}{0.913} & \multirow{5}{*}{0.679} \\
\hline & & EE2 & 0.804 & & & \\
\hline & & EE3 & 0.844 & & & \\
\hline & & EE4 & 0.823 & & & \\
\hline & & EE5 & 0.794 & & & \\
\hline & \multirow{5}{*}{$\begin{array}{c}\text { Process } \\
\text { management }\end{array}$} & PM1 & 0.900 & \multirow{5}{*}{0.929} & \multirow{5}{*}{0.946} & \multirow{5}{*}{0.779} \\
\hline & & PM2 & 0.898 & & & \\
\hline & & PM3 & 0.831 & & & \\
\hline & & PM4 & 0.908 & & & \\
\hline & & PM5 & 0.874 & & & \\
\hline & \multirow{4}{*}{$\begin{array}{l}\text { Continuous } \\
\text { improvement }\end{array}$} & CI1 & 0.845 & \multirow{4}{*}{0.933} & \multirow{4}{*}{0.949} & \multirow{4}{*}{0.789} \\
\hline & & $\mathrm{CI} 2$ & 0.879 & & & \\
\hline & & CI3 & 0.856 & & & \\
\hline & & CI4 & 0.879 & & & \\
\hline
\end{tabular}




\begin{tabular}{|c|c|c|c|c|c|c|}
\hline & & CI5 & 0.783 & & & \\
\hline \multirow{10}{*}{ 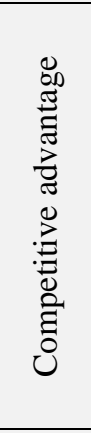 } & \multirow{10}{*}{$\begin{array}{l}\text { Competitive } \\
\text { advantage }\end{array}$} & CA1 & 0.881 & \multirow{10}{*}{0.954} & \multirow{10}{*}{0.960} & \multirow{10}{*}{0.707} \\
\hline & & CA2 & 0.852 & & & \\
\hline & & CA3 & 0.852 & & & \\
\hline & & CA4 & 0.890 & & & \\
\hline & & CA5 & 0.865 & & & \\
\hline & & CA6 & 0.813 & & & \\
\hline & & CA7 & 0.836 & & & \\
\hline & & CA8 & 0.877 & & & \\
\hline & & CA9 & 0.877 & & & \\
\hline & & CA10 & 0.791 & & & \\
\hline \multirow{8}{*}{ 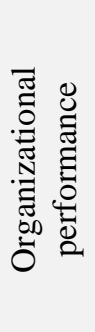 } & \multirow{8}{*}{$\begin{array}{l}\text { Organizational } \\
\text { performance }\end{array}$} & OP1 & 0.867 & \multirow{8}{*}{0.932} & \multirow{8}{*}{0.944} & \multirow{8}{*}{0.679} \\
\hline & & OP2 & 0.820 & & & \\
\hline & & OP3 & 0.890 & & & \\
\hline & & OP4 & 0.891 & & & \\
\hline & & OP5 & 0.799 & & & \\
\hline & & OP6 & 0.783 & & & \\
\hline & & OP7 & 0.760 & & & \\
\hline & & OP8 & 0.771 & & & \\
\hline
\end{tabular}

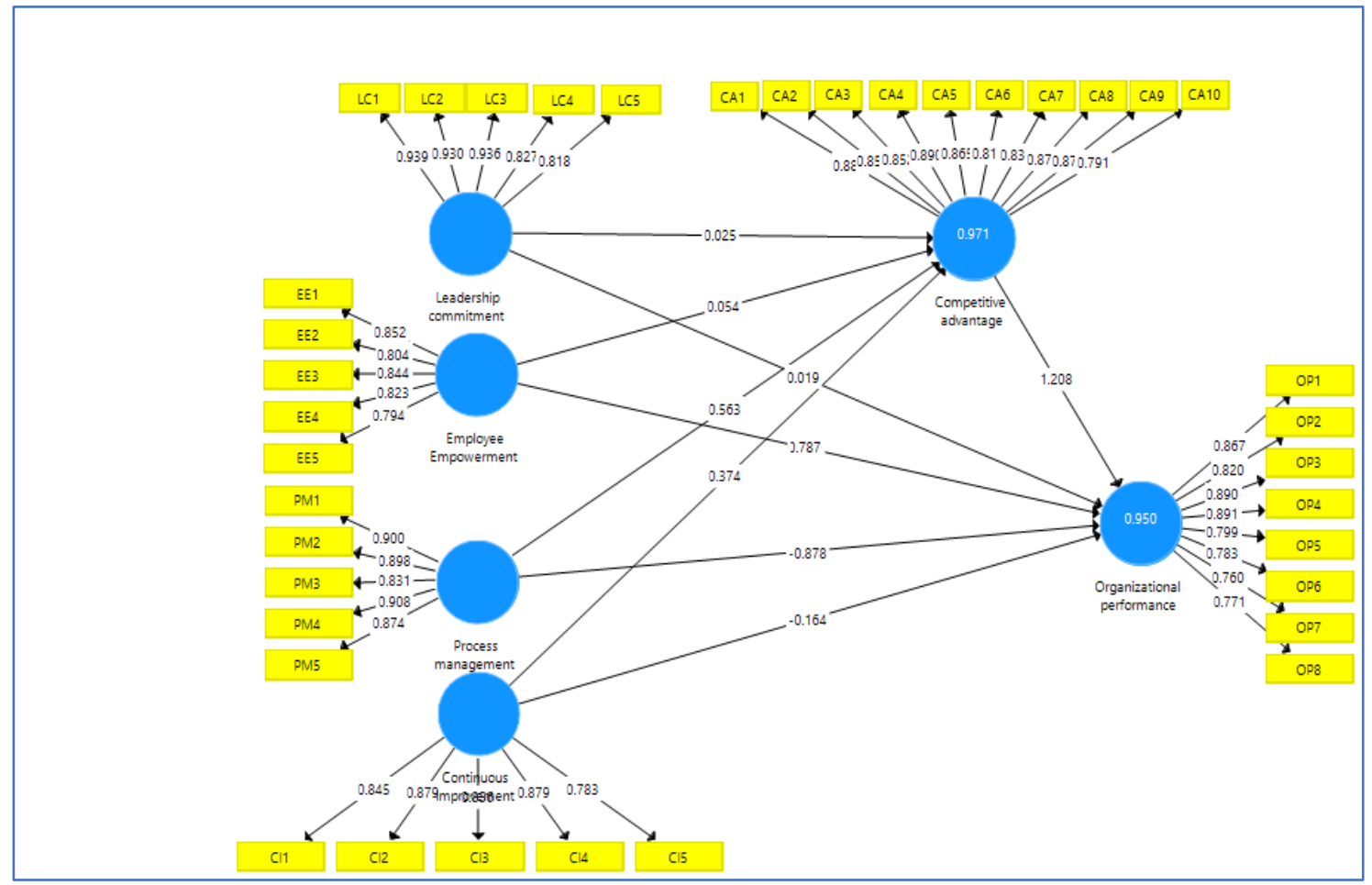

As Table 3 reveals., the correlation of latent variables and discriminant validity (Fornell-Larcker) Squared correlations were lower than the corresponding AVE estimates between the variables. This finding indicates that the constructs had a stronger relationship to their respective indicators; the result indicated that the measure had adequate discriminant validity.

Table 3: Correlation of latent variables and discriminant validity

\begin{tabular}{|c|c|c|c|c|c|c|}
\hline Variables & LC & EE & PM & CI & CA & OP \\
\hline LC & 0.824 & & & & & \\
\hline EE & 0.752 & 0.888 & & & & \\
\hline PM & 0.675 & 0.468 & 0.825 & & & \\
\hline
\end{tabular}




\begin{tabular}{|l|l|l|l|l|l|l|}
\hline CI & 0.567 & 0.536 & 0.517 & 0.892 & & \\
\hline CA & 0.634 & 0.642 & 0.637 & 0.545 & 0.841 & \\
\hline OP & 0.546 & 0.538 & 0.674 & 0.579 & 0.567 & 0.883 \\
\hline
\end{tabular}

Furthermore, about the explanation of the convergent reliability, it is significant for assessing the distinctiveness for the variables. In this manner, the researcher has used HTMT is the association ratio of attributes to attribute correlations. HTMT is the mean for all associations between indicators measuring various combinations in comparison with the average links among indicators measuring the same structure
(Sarstedt et al., 2016). HTMT was also performed to assess discriminatory validity. HTMT's approach is to estimate the relationship between structures.

Hair (2017) suggested that the value of HTMT be smaller than 0.85 , which meant that the combinations were distinct. Table 4 reveals the HTMT values for all variables in this paper below 0.85 . Consequently, adequate discriminatory structures were offered.

Table 4: Correlation of latent constructs and discriminant validity (HTMT method)

\begin{tabular}{|c|c|c|c|c|c|c|}
\hline Variables & LC & EE & PM & CI & CA & OP \\
\hline LC & & & & & & \\
\hline EE & 0.648 & & & & & \\
\hline PM & 0.775 & 0.591 & & & & \\
\hline CI & 0.652 & 0.540 & 0.612 & & & \\
\hline CA & 0.479 & 0.526 & 0.533 & 0.564 & & \\
\hline OP & 0.794 & 0.565 & 0.720 & 0.726 & 0.642 & \\
\hline
\end{tabular}

\subsection{Hypotheses Testing (Path Coefficient)}

The final step in evaluating the structural model is examining the research hypotheses through assessing the path coefficient. The less the p-value, the more significant the relationship is (Hair et al., 2017). Table 5 shows below the direct relationship results of the structural model, the relationship between hypothesis as H1, H2, H3, H4, H5, H6, H7, H8, H9.

Table 5: Direct results of hypotheses

\begin{tabular}{|c|c|c|c|c|c|c|}
\hline Hypothesis & $\begin{array}{c}\text { Path } \\
\text { Coefficient }(\beta)\end{array}$ & Std. Error & T-value & P-value & Inference & Decision \\
\hline LC-CA & 0.202 & 0.063 & 3.218 & 0.001 & Significant $*$ & Supported \\
\hline EE-CA & 0.360 & 0.102 & 3.524 & 0.000 & Significant ** & Supported \\
\hline PM-CA & 0.385 & 0.052 & 7.434 & 0.000 & Significant ** & Supported \\
\hline CI-CA & 0.224 & 0.059 & 3.812 & 0.000 & Significant ** & Supported \\
\hline LC-OP & 0.173 & 0.053 & 3.282 & 0.001 & Significant * & Supported \\
\hline EE-OP & 0.624 & 0.077 & 8.114 & 0.000 & Significant ** & Supported \\
\hline PM-OP & 0.055 & 0.021 & 2.580 & 0.010 & Significant $*$ & Supported \\
\hline CI-OP & 0.307 & 0.068 & 4.519 & 0.000 & Significant $* *$ & Supported \\
\hline CA-OP & 0.666 & 0.078 & 8.578 & 0.000 & Significant ** & Supported \\
\hline
\end{tabular}

\subsection{Testing the Mediation Relationship (Indirect Effects)}

The theoretical design of this paper provides a unique opportunity to test whether competitive advantagemediate the relationship between TQM practices and OP. Hayes (2009) define the mediator as a variable that accounts for all or part of the relationship between a predictor and outcome. The predictor in this paper is (TQMP) while the outcome is the competitive advantage. Table 6displays the effects for the mediating variable of the indirect effect.

Table 6: Results of the Specific Indirect Effects (Mediation Test)

\begin{tabular}{|c|c|c|c|c|c|c|}
\hline Hypothesis & $\begin{array}{c}\text { Path } \\
\text { Coefficient }(\beta)\end{array}$ & $\begin{array}{c}\text { Std. } \\
\text { Error }\end{array}$ & T-value & P-value & Inference & Decision \\
\hline CL-CA-OP & 0.407 & 0.053 & 7.638 & 0.000 & Significant $* *$ & Supported \\
\hline EE-CA-OP & 0.076 & 0.030 & 2.522 & 0.001 & Significant $*$ & Supported \\
\hline PM-CA-OP & 0.197 & 0.070 & 2.580 & 0.000 & Significant $* *$ & Supported \\
\hline
\end{tabular}




\begin{tabular}{|l|l|l|l|l|l|l|}
\hline CI-CA-OP & 0.594 & 0.061 & 9.815 & 0.000 & Significant $* *$ & Supported \\
\hline
\end{tabular}

The important information presented in Tables 4,5 of transactions is the statistical significance of each dependent variable. The value of $t$ and the value of $p$ tell us if the coefficients of the variables are zero in the population. If $\mathrm{p}$ is less than 0.005 , We may conclude that the variables are statistically significant. In our case, we may see from the table that all independent variables have a positive effect and that the p-values for all independent variables are less than 0.05 . Hence, a reasonable conclusion can state that a significant and positive impact, and we reject our empty assumptions and thus support the assumptions:

H1: There is a positive relationship between leadershipcommitment and competitive advantage.

$\mathrm{H} 2$ : There is a positive relationship between employeeempowerment and competitive advantage.

H3: There is a positive relationship between processmanagementand competitive advantage.

H4: There is a positive relationship between continuousimprovementand competitive advantage.

H5: There is a positive relationship between leadership commitment and organizational performance.

H6: There is a positive relationship between employee empowerment and organizational performance.

H7: There is a positive relationship between process management and organizational performance.

H8: There is a positive relationship between continuous improvement and organizational performance.

H9: There is a positive relationship between competitive advantage and organizational performance.

H10: There is a positive relationship between leadership commitment indirectly affects anorganizational performance through competitive advantage as an intermediate variable.

H11: There is a positive relationship between employee empowermentindirectly affects an organizational performance through competitive advantage as an intermediate variable.

H12: There is a positive relationship between process management indirectly affects an organizational performance through competitive advantage as an intermediate variable.

H13: There is a positive relationship between continuous improvement indirectly affects an organizational performance through competitive advantage as an intermediate variable.

\subsection{Discussion}

In the previous section, the overall results of this paper are presented through different statistical methods and measures. However, this section is about the discussion of key research findings.

Firstly, the test for the measurement model has been carried out to test the reliability of each variable. In this regard, the values of composite reliability, Cronbach Alpha, and outer loading of all the variables are identified, as above the threshold, thus there was no need to drop any factor or variable from this paper. Apart from that, the distinctiveness and similarity of the variables have been tested through the HTMT ratio. With respect to the results of HTMT ratio, no variable was found to violate the criteria of HTMT ratio; hence, all the variables were qualified for path analysis.

From the summary of findings, it is clear that the TQM practices had an effect on CA and OP at SMEs in Iraq.

The paper found that the four independent variables in the study (Leadership commitment, Employee Empowerment, Process management, Continuous improvement) influenced organizational performance by competitive advantage as mediating.

This finding further supports the results of the research by (Flynn et al., 1995; Lakhal, 2009; Munizu, 2013;Saleh et al., 2018; Alnuaimi \& Yaakub, 2020). The findings provided sufficient evidence to reject the null hypothesis and established that TQM practices influence the competitive advantage and organizational performance of SMEs positively.

\section{Conclusions, Limitations and Future Research and recommendations$$
\text { 5.1Conclusions }
$$

The aim of this paper was to test the impact of TQM practices on competitive advantage and organizational performance at SMEs in Iraq.

The findings revealed that TQM practices (Leadership commitment, Employee Empowerment, Process management, Continuous improvement) and competitive advantage play a key role in improving organizational performance. Additionally, the competitive advantage positively contributes to improving the organizational performance of companies.

More importantly, the competitive advantage mediates the relationship between TQM practices (Leadership commitment, Employee Empowerment, Process management, Continuous improvement) and the organizational performance, in which both direct 
and indirect effects do exist and point in the same direction (i.e., denoting a positive relationship).

Hence, the higher the level of TQM practices implementation, the higher the CA and OP.

According to the aims of this paper, the researcher also confirms that both TQM practices and competitive advantage influence the organizational performance positively which, in turn, supports the study hypotheses.

\subsection{Limitations and Future Research}

This paper is selective and offers opportunities for further studies. However, the paper findings are limited by its focus only on companies of manufacturing. Further research could be done in the service sector of the country to generalize the results of this paper or indicate a need to modify the related concepts.

Second, self-reported data were used, possible interference with the survey cannot be ruled out because the respondents' interpretation and answers are not inherently impartial. A future study could use an on-site survey process with a researcher helping the respondent during the questionnaire without guaranteeing that the employees will complete the survey personally.

Finally, qualitative research on Total Quality Management a deeper understanding of how companies manage them is very necessary. Future research will conduct interviews or conduct on-site visits with executives and employees to further explore these activities.

\subsection{Recommendations}

The following recommendations are Based on the results of this paper:

Companies should fully implement TQM practices to ensure quality management and delivery of goods and services to their customers.

The TQM should periodically arrange properly planned training programs for employees. This means that TQM's best practices also help to build a competitive advantage.

Companies should constantly interact with their clients or customers to offer technical advice, especially to business owners to grow their businesses, this will make them unique and hence achieve a competitive advantage.

\section{Disclosure statement}

The writers have not identified any possible conflicts of interest.

\section{REFERENCES}

Addae-Korankye, A. (2013). Total Quality Management (Tqm): a Source of Competitive Advantage. a Comparative Study of
Manufacturing and Service Firms in Ghana. International Journal of Asian Social Science, 3(6), 1293-1305.

Agha, S., Alrubaiee, L., \& Jamhour, M. (2012). Effect of Core Competence on Competitive Advantage and Organizational Performance. International Journal of Business and Management, 7(1), 192-204.

Alnuaimi, A. S. A., \& Yaakub, K. B. (2020). The Impact of Leadership Practices on Total Quality Management and Organizational Performance in the UAE Interior Ministry. European Journal of Multidisciplinary Studies, $5(2)$, $5-12$. https://doi.org/10.26417/ejms.v5i2.p10-15

Anwar, M. (2018). business model innovation and smes performance — does competitive advantage mediate? International Journal of Innovation Management, 22(07), 1850057.

Awino, Z. B., Muchara, M., Ogutu, M., \& Oeba, L. K. (2012). Total quality and competitive advantage of firms in the horticultural industry in Kenya. Prime Journal of Business Administration and Management, 2(4), 22511261. www.primejournal.org/BAM

Azizi, R., Maleki, M., Moradi-Moghadam, M., \& Cruz-Machado, V. (2016). The impact of knowledge management practices on supply chain quality management and competitive advantages. Management and Production Engineering Review, 7(1), 4-12. https://doi.org/10.1515/mper-2016-0001

Bani, S. A. S., Nordin, N. M., \& Hanafi, H. F. (2018). Exploring the conceptual framework in e-magazine portal development in malaysia: A case study on media glam. International Journal of Innovative Technology and Exploring Engineering, 8(2), 392-397.

Chege, S. W., \& Bett, S. (2019). Total Quality Management Practices and Performance of Organizations in the Real Estate Industry, Case of Property Developers in Nairobi City County, Kenya. International Journal of Current Aspects, 3(IV), 14-31. https://doi.org/10.35942/ijcab.v3iiv.44

Davcik, N. S. (2016). Marketing resources, performance, and competitive advantage: A review and future research directions. Journal of Business Research, 102,(351), 49-58.

Douglas, T. J., \& Judge, W. (2001). TQM implementation and competitive Advantage Structural control and exploration. Academy of Management Journal, 44(1), 158-189.

Eniola, A., \& Ektebang, H. (2014). SME firms performance in Nigeria: Competitive advantage and its impact. International Journal of 
Research Studies in Management, 3(2), 75-86. https://doi.org/10.5861/ijrsm.2014.854

Esiaba, L. A. (2016). Total Quality Management Practices and Competitive advantage in the Aviation Industry in Kenya (Vol. 10, Issue November).

http://erepository.uonbi.ac.ke/bitstream/handle/ 11295/100186/Esiaba_Total Quality Management Practices And Competitive Advantage In The Aviation Industry In Kenya.pdf?sequence $=1 \&$ isAllowed $=y$

Falih, F. S., Kasim, R., Yaseen, M. H., Sabah, M. I. A., \& Kadhim, K. G. (2020). The Relationship of Operational Risk Management and Competitive Advantages in enhancing the Iraqi Banking Sector. Solid State Technology, 63(6), 2426-2438.

Flynn, B. B., Schroeder, R. G., \& Sakakibara, S. (1995). The Impact of Quality Management Practices on Performance and Competitive Advantage. Decision Sciences, 26(5), 659-691. https://doi.org/10.1111/j.1540-

5915.1995.tb01445.x

Hair, J., Hult, T. M., Ringle, C. M., \& Sarstedt, M. (2017). A Primer on Partial Least Squares Structural Equation Modeling (PLS-SEM) (Second Edi).

Hayes, A. F. (2009). Statistical Mediation Analysis in the New Millennium. Communication Monographs, 76(4), 408-420. https://doi.org/10.1080/03637750903310360

Kaleka, A., Morgan, N. A., \& ABSTRACT. (2017). Which Competitive Advantage(s)? International Markets Performance Relationships in Competitive AdvantageMarket. Journal of International Marketing, 25(4), 25-49.

Kamukama, N., Ahiauzu, A., \& Ntayi, J. M. (2011). Competitive advantage: mediator of intellectual capital and performance. Journal of Intellectual Capital, 12(1), 152-164.

Kang, S., \& Na, Y. K. (2020). Effects of strategy characteristics for sustainable competitive advantage in sharing economy businesses on creating shared value and performance. In Sustainability (Switzerland) (Vol. 12, Issue 4). https://doi.org/10.3390/su12041397

Kannan, V. R., \& Tan, K. C. (2005). Just in time , total quality management, and supply chain management: understanding their linkages and impact on business performance. The International Journal of Management Science, 33 ,

$153-162$. https://doi.org/10.1016/j.omega.2004.03.012

Khan, M. W. J., Alam, M. B., Sulaiman, G., \& Ahmed, Z. (2020). Nexus between Total
Quality Management Practices and Construction Firms' Performance in Pakistan. Review of Economics and Development Studies, 6(4), 787-798.

Kiprotich, A. M., Njuguna, R., \& Kilika, J. (2018). Total Quality Management Practices and Operational Performance of Kenya Revenue Authority. International Journal of Contemporary Aspects in Strategic Management (IJCASM), 2(I), 91-105.

Laframboise, K., \& Reyes, F. (2005). Gaining competitive advantage from integrating enterprise resource planning and total quality management. Journal of Supply Chain Management, 41(3), 49-64. https://doi.org/10.1111/j.10556001.2005.04103005.x

Lakhal, L. (2009). Impact of quality on competitive advantage and organizational performance. Journal of the Operational Research Society, 60, 637-645.

Lestari, S. D., Leon, F. M., Widyastuti, S., Brabo, N. A., \& Putra, A. H. P. K. (2020). Antecedents and consequences of innovation and business strategy on performance and competitive advantage of SMEs. Journal of Asian Finance, Economics and Business, 7(6), 365-378. https://doi.org/10.13106/JAFEB.2020.VOL7.N O6.365

Li, S., Ragu-Nathan, B., Ragu-Nathan, \& Rao, S. (2006). The impact ofsupplychain management practices on competitive advantage and organizational performance. Evaluation and Program Planning, 34, 107-124. https://doi.org/10.1016/j.evalprogplan.2020.101 801

Morgan, N. A., Katsikeas, C. S., \& Vorhies, D. W. (2012). Export marketing strategy implementation, export marketing capabilities , and export venture performance. Journal of the Academy of Marketing Science, 40(2), 271289. https://doi.org/10.1007/s11747-011-02750

Munizu, M. (2013). The impact of total quality management practices towards competitive advantage and organizational performance: Case of fishery industry in South Sulawesi Province of Indonesia. Journal of Commerce and Social Sciences, 7(1), 184-197.

Nguyen, V. C., \& Chau, N. T. (2017). Research framework for the impact of total quality management on competitive advantage The mediating role of innovation performance. Review of International Business and Strategy, 27(3), 335-351.

Obeidat, B., Tawalbeh, H. F., \& Masa'deh, R. 
(2019). Reviewing the Literature among Human Resource Management (HRM) Practices, Total Quality Management (TQM) Practices and Competitive Advantages. Journal of Social Sciences, 8(2), 327-358. https://doi.org/10.5539/mas.v12n11p17

Othman, B., Khatab, J. J., Esmaeel, E. S., Mustafa, H. A., \& Sadq, Z. M. (2020). The Influence of Total Quality Management on Competitive Advantage towards Bank Organizations: Evidence from Erbil/Iraq. International Journal of Psychosocial Rehabilitation, 24(5), 34273439.

Pham, T. M. D. (2020). On the relationship between total quality management practices and firm performance in Vietnam: The mediating role of non-financial performance Thi. Management Science Letters Homepage:, 10, 1743-1754.

Phan, A. C., Nguyen, H. T., Nguyen, H. A., \& Matsui, Y. (2019). Effect of Total Quality Management Practices and JIT Production Practices on Flexibility Performance: Empirical Evidence from International Manufacturing Plants. Sustainability, 11(11), 2-21.

ROSE, R. C., ABDUllAH, H., \& ISMAD, A. I. (2010). A Review on the Relationship between Organizational Resources, Competitive Advantage and Performance. Journal of International Social Research, 3(11), 488-498.

Rui Chen, Y.-D.-H. W. L. (2018). Total quality management and sustainable competitive advantage: serial mediation of transformational leadership and executive ability. Total Quality Management \& Business Excellence, 31(5-6), 451-468.
Saleh, R. A., Sweis, R. J., \& Saleh, F. I. M. (2018). Investigation the impact of hard total quality management practices on operational performance in manufacturing organizations: evidence from Jordan. Benchmarking: An International Journal.

Sarstedt, M., Hair, J. F., Ringle, C. M., Thiele, K. O., \& Gudergan, S. P. (2016). Estimation issues with PLS and CBSEM : Where the bias lies! 2. Journal of Business Research, 69(10), 3998-4010. https://doi.org/10.1016/j.jbusres.2016.06.007

Singh, P. J., \& Smith, A. (2006). Total Quality Management \& Business Excellence Uncovering the Faultlines in Quality Management. Total Quality Management \& Business Excellence, 17(3), 395-407. https://doi.org/10.1080/14783360500451648

Suresh, K., \& Ganesan, M. (2020). A study on the role of Total Quality Management practices in improving Employee Performance. Journal of Engineering and Scienes, 11(4), 1029-1038.

Yanya, \& Mahamat. (2020). the impact of supply chain management practices on competitive advantages: moderation role of total quality management. polish journal of management studies, 21(1), 419-431.

Zhou, K. Z., Brown, J., \& Dev, C. S. (2009). Market Orientation, Competitive Advantage, and Performance: A Demand-Based Perspective. Journal of Business Research,62(11), 10631070 . 